\title{
PENGARUH KOMPETENSI, KOMITMEN DAN PENGEMBANGAN KARIR TERHADAP KINERJA KARYAWAN PADA PT. PRUDENTIAL LIFE ASSURANCE RANTAUPRAPAT
}

\author{
Suji Adelina Ritonga ${ }^{1}$, Desmawaty Hasibuan ${ }^{2}$
}

Alumni Sarjana Ekonomi STIE Labuhanbatu ${ }^{2}$ Dosen STIE Labuhanbatu

\begin{abstract}
ABSTRAK
Penelitian ini bertujuan untuk menganalisis pengaruh kompetensi secara parsial terhadap kinerja karyawan PT. Prudential Life Assurance Rantauprapat. Untuk menganalisis pengaruh komitmen secara parsial terhadap kinerja karyawan PT. Prudential Life Assurance Rantauprapat. Untuk mengetahui pengaruh pengembangan karir secara parsial terhadap kinerja karyawan PT. Prudential Life Assurance Rantauprapat. Untuk mengetahui pengaruh kompetensi, komitmen dan pengembangan karir secara serempak terhadap kinerja karyawan PT. Prudential Life Assurance Rantauprapat. Subjek penelitian ini dilakukan pada PT. Prudential Life Assurance Rantauprapat dengan populasi berjumlah 45 orang sehingga seluruh populasi tersebut merupakan sampel keseluruhan dengan teknik sampling jenuh. Teknik pengumpulan data dilakukan dengan kuesioner atau data sekunder. Teknik analisis data menggunakan deskriptif statistic dan analisis regresi linier berganda. Hasil penelitian menunjukkan secara serempak variabel kompetensi, komitmen dan pengembangan karir berpengaruh positif dan signifikan terhadap kinerja karyawan, secara parsial parsial kompetensi berpengaruh positif dan signifikan terhadap kinerja karyawan, secara parsial komitmen tidak berpengaruh positif dan tidak signifikan terhadap kinerja karyawan dan secara parsial pengembangan karir berpengaruh positif dan signifikan terhadap kinerja karyawan.
\end{abstract}

Kata Kunci : Kompetensi, Komitmen, Pengembangan Karir, Kinerja Karyawan.

\section{PENDAHULUANPENDAHULUAN}

\section{Latar Belakang Masalah}

Kinerja karyawan dapat dipengaruhi bahkan bergantung pada tingkat kompetensi yang dimiliki karyawan dalam perusahaan. Kompetensi karyawan memiliki peranan penting untuk mencapai kinerja yang telah direncanakan oleh perusahaan sebelumnya. Perubahan lingkungan bisnis yang tinggi semakin mengarahkan pada pengakuan pentingnya Sumber Daya Manusia sebagai

sumber keunggulan bersaing yang mempunyai kompetensi tinggi dipandang dapat mendukung peningkatan kinerja karyawan.

Menurut Shaputra dan Hendriani (2015) penelitiannya membuktikan bahwa variabel kompetensi memiliki pengaruh besar terhadap kinerja karyawan. Kompetensi sebagai 
karakteristik dasar dari seseorang yang memungkinkan karyawan mengeluarkan kinerja superior dalam pekerjaannya.

Kompetensi merupakan bagian kepribadian yang mendalam dan melekat pada seseorang dengan perilaku yang dapat diprediksi pada berbagai keadaan dan tugas pekerjaan.

Kompetensi dapat digunakan sebagai kriteria utama untuk menilai kerja seseorang. Misalnya, untuk fungsi profesional, manajerial atau senior manajer. Karyawan-karyawan yang ditempatkan pada tugas-tugas tersebutakan mengetahui kompetensi-kompetensi apa saja yang diperlukan, serta cara apa yang harus ditempuh untuk mencapai promosi ke jenjang posisi berikutnya. Kinerja karyawan dalam organisasi haruslah bersifat menyeluruh dan menjamah semua elemen, karena unsur atau input yang didayagunakan oleh organisasi untuk meningkatkan kinerja organisasi.

Faktor penting untuk meningkatkan kinerja karyawan adalah bagaimana menciptakan strategi untuk membangun komitmen karyawan terhadap organisasinya. Karyawan yang berkomitmen terhadap organisasi merupakan salah satu tantangan yang paling sulit dihadapi oleh pihak manajemen organisasi. Mempekerjakan karyawan yang berkualitas memang tidaklah mudah, tetapi membangun komitmen karyawan jauh lebih sulit karena memerlukan keyakinan. Sebagaimana dengan hasil penelitian

RimpulaengdanSepang(2014) membuktikanbahwakomitmen karyawan berpengaruhbaik terhadapkinerja karyawan. Manajemen sumber daya manusia pada dasarnya adalahlangkahlangkah perencanaan, penarikan,seleksi, pengembangan, pemeliharaan, dan penggunaan sumber daya manusia untuk mencapai tujuan individu maupun organisasi. Oleh karena itu keberhasilan pengelolaan organisasi sangat ditentukan oleh kegiatan pendayagunaan sumber daya manusia, karena sumber daya manusia sangat penting artinya dalam menentukan kelangsungan hidup suatu organisasi.

Pengembangan karir mempengaruhi kinerja karyawan, dimana pengembangan karir merupakan pendekatan formal yang dilakukan organisasi untuk menjamin orang-orang dalam organisasi mempunyai

kualifikasi dan kemampuan serta pengalaman yang cocok ketika dibutuhkan. Oleh karena itu, perusahaan perlu mengelola karir dan mengembangkannya dengan baik supaya kinerja karyawan tetap terjaga dan mampu mendorong karyawan untuk selalu melakukan hal yang terbaik sesuai dengan penelitian oleh Kaseger (2013) bahwa pengembangan karir berpengaruh terhadap kinerja. Pengembangan karir menunjukkan adanya peningkatan status seseorang dalam suatu organisasi pada jalur karir yang telah ditetapkan dalam organisasi yang bersangkutan.

PT. Prudential Life Assurance Rantauprapat merupakan salah satu perusahaan yang bergerak dibidang jasa, dimana salah satu usaha yang dilakukannya adalah mencari tenaga kerja yang berkualitas sehingga dapat dipercaya oleh nasabah-nasabah yang akan ikut serta dalam perusahaan tersebut sehingga PT. Prudential Life Assurance Rantauprapat dapat dipercaya oleh nasabah dan memiliki citra perusahaan yang baik. 
Kondisi yang demikian perlu kiranya mendapat perhatian lebih dalam dari pihak manajemen PT. Prudential Life Assurance Rantauprapat yang berkaitan dengan kompetentsi, komitmen dan pengembangan karir karyawan, dari penjelasan secara teori yang didukung penelitian terdahulu, maka penulis melakukan penelitian ini akan mencoba menjelaskan pengaruh kompetensi, komitmen dan pengembangan karir terhadap kinerja karyawan PT. Prudential Life Assurance Rantauprapat.

\section{Rumusan Masalah}

Rumusan masalah pada penelitian ini, yaitu :

1. Apakah kompetensi secara parsial berpengaruh terhadap kinerja karyawan PT. Prudential Life Assurance Rantauprapat?

Apakah komitmen secara parsial berpengaruh terhadap kinerja karyawan PT. Prudential Life Assurance Rantauprapat?

Apakah pengembangan karir secara parsial berpengaruh terhadap kinerja karyawan PT. Prudential Life Assurance Rantauprapat?

Apakah kompetensi, komitmen dan pengembangan karir secara serempak berpengaruh terhadap kinerja karyawan PT. Prudential Life Assurance Rantauprapat ?

\section{Tujuan Penelitian}

Adapun tujuan penelitian ini adalah :

1. Untuk menganalisis pengaruh kompetensi secara parsial terhadap kinerja karyawan PT.

Prudential Life Assurance Rantauprapat.

Untuk menganalisis pengaruh komitmen secara parsial terhadap kinerja karyawan PT. Prudential Life Assurance Rantauprapat.

Untuk mengetahui pengaruh pengembangan karir secara parsial terhadap kinerja karyawan PT. Prudential Life Assurance Rantauprapat.

Untukmengetahuipengaruh

kompetensi,komitmendan

pengembangan karir secara serempak terhadap kinerja karyawan PT. Prudential Life Assurance Rantauprapat.

Manfaat Penelitian Manfaat daripenelitian ini antara lain : 
1. Bagi Penulis Sebagai wadah untuk menggali potensi diri dalam meningkatkan kemampuan, kompetensi dan komitmen dalam perusahaan selama studi di Sekolah Tinggi

Ilmu Ekonomi (STIE) Labuhanbatu pada program studi

manajemen khususnya bidang manajemen yang berkaiatan dengan sumber daya manusia.

2. Bagi Perusahaan Sebagai landasan PT. Prudential Life Assurance Rantauprapat untuk menilai kinerja karyawanuntukdapat menempatkan karyawan yang berkualitas. 3. Bagi Peneliti Lain Dapat menjadi inspirasi bagi peneliti lain yang

akan melakukan penelitian tentang variabel yang sama.

\section{TINJAUAN PUSTAKA Penelitian Terdahulu}

Penelitian terdahulu yang mendukung pada penelitian ini sebagai berikut :

a. Penelitian oleh Shaputra dan Hendriani (2015) berjudul "Pengaruh Kompetensi, Komitmen Dan PengembanganKarir Terhadap Kinerja Karyawan PT. Bank Rakyat Indonesia (Persero) Kantor Wilayah Pekanbaru”. Penelitian ini bertujuan mencari pengaruh signifikan antara kompetensi, komitmen dan pengembangan karir terhadap kinerja karyawan PT. Bank Rakyat Indonesia (Persero) Kantor Wilayah Pekanbaru. Teknik analisis pada penelitian ini adalah deskriptik statistik dan statistik inferensial multi regresi dengan metode survey. Populasi penelitian berjumlah 1101 karyawan PT Bank Rakyat Indonesia (Persero) Kantor Wilayah Pekanbaru, sampel pada penelitian ini berjumlah 294 respon. Hasilpenelitiansecaraparsialkompetensi dan komitmen berpengaruh terhadap kinerjakaryawan,sedangkanpengembangan karir tidak berpengaruh terhadap kinerja karyawan.

b.Penelitian Kaseger (2014) berjudul "Pengembangan Karir Dan Self-Efficacy Terhadap Kinerja Karyawan Pada PT. Matahari Department Store Manado Town Square". Tujuan penelitian ini untuk mengetahui apakah pengembangan karir dan self-efficacy berpengaruhterhadap kinerja karyawan pada PT. Matahari Department Store Manado Town Square. Data dianalisis menggunakanregresilinear berganda. Pemilihan sampel menggunakan purposive sampling, sebanyak 50 orang. Hasil penelitian diperoleh bahwa pengembangan karir dan selfefficacy secara bersama berpengaruh signifikan terhadap kinerja karyawan. Pengembangan karirberpengaruhsignifikan terhadapkinerja karyawan, sedangkan self-

efficacytidak signifikan terhadap kinerja karyawan.

\section{Uraian Teori Kompetensi}

Kompetensi sebagai kemampuan seseorang untuk menghasilkan pada tingkat yang memuaskan ditempat kerja termasuk diantaranya seseorang untuk mentrasfer dan mengaplikasikan keterampilan dan pengetahuan tersebut dalam situasi yang baru. Kompetensi terdiri dari 5 (lima) tipe karakteristik, yaitu motif (kemauan konsisten), faktor bawaan (karakter dan respon 
yang konsisten), konsep diri (gambaran diri), pengetahuan (informasi dalam bidang tertentu) dan keterampilan (kemampuan untuk melaksanakan tugas).

Hal ini sejalan dengan pendapat Becker dan Ulrich dalam Suparno (2005) bahwa kompetensi mengandung aspekaspek pengetahuan, ketrampilan (keahlian) dan kemampuan ataupun karakteristik kepribadian yang mempengaruhi kinerja. Pengertian kompetensi yang dikemukakan oleh para ahli, menurut Wibowo (2010) mengemukakan bahwa suatu kemampuan untuk malaksanakan atau melakukan suatu pekerjaan atau tugas yang dilandasi atas keterampilan dan pengetahuan serta didukung oleh sikap kerja yang dituntut oleh pekerjaan itu tersebut.

Pengukuran kompetensi harus dilakukan guna mengetahui tingkat pencapaian sesuai dengan standar kompetensi yang ditetapkan, sehingga pada akhirnya terdapat keputusan apakah pegawai yang bersangkutan berkompeten atau tidak berkompeten dalam jabatan pekerjaan tersebut. Menurut Manopo, (2011) penilaian kompetensi atau model kompetensiadalah mengidentifikasi keahlian, pengetahuan dan karakteristik pribadi yang dibutuhkan untuk mencapai kinerja terbaik dalam pekerjaanya.

Penilaian kompetensi ini dilakukan dengan memastikan para pegawai mendapatkan pelatihan dan pengembangan yang diperlukan untuk merealisasikan dan meningkatkan potensi yang dimiliki. Penilaian kompetensi diaplikasikan pada suatu organisasi yang dilakukan pada saat organisasi akan memutuskan kriteria kesuksesan yang tepat dan menghubungkannya dengan kemampuan yang dibutuhkan oleh seseorang pegawai untuk melaksanakan pekerjaannya. Pelaksanaan penilaian kompetensi dengan cara mengidentifikasi aspek-aspek yang memberi kontribusi terhadap kesuksesan yang dicapai oleh pegawai yang menghasilkan kinerja terbaik didalam organisasi tersebut. Dari pengertian kompetensi tersebut di atas, terlihat bahwa fokus kompetensi adalah untuk memanfaatkan pengetahuan dan ketrampilan kerja guna mencapai kinerja optimal.

Berbagai pendapat tersebut dapat dipahami bahwa kompetensi menunjuk pada kinerja seseorang dalam suatu pekerjaan yang bisa dilihat dari pikiran, sikap, dan perilaku. Lebih lanjut Manopo (2011), membagi 5 (lima) karakteristik kompetensi yaitu sebagai berikut :

Motif, yaitu sesuatu yang orang pikirkan dan inginkan yang menyebabkan sesuatu.

Sifat, yaitu karakteritik fisik

tanggapan konsisten terhadap situasi.

Konsep diri, yaitu sikap, nilai, dan image dari sesorang.

Pengetahuan, yaitu informasi yang dimiliki seseorang dalam bidang tertentu. 
Ketrampilan, yaitu kemampuan untuk melakukan tugas-tugas yang berkaitan dengan fisik dan mental.

\section{Komitmen}

Sumber daya manusia adalah aset perusahaan yang harus dijaga dan dipelihara agar karyawan yang berkualitas tetap berada diperusahaan, untuk mewujudkan hal

tersebut karyawan harus memiliki komitmen. Komitmen adalah sikap yang mencerminkan sejauh mana seorang individu mengenal dan terikat pada organisasinya. Karyawan yang berkomitmen dan berkualitas biasanya selalu dapat diandalkan dan akan mencurahkan kemampuannya secara maksimal.

Pengertian komitmen karyawan menurut Steers dalam Kuntjoro (2006) adalah rasa identifikasi, keterlibatan dan loyalitas yang dinyatakan oleh seorang pegawai terhadap organisasinya. Komitmen karyawan merupakan kondisi dimana pegawai sangat tertarik terhadap tujuan, nilainilai, dan sasaran organisasinya. Komitmen terhadap organisasi artinya lebih dari sekedar keanggotaan formal, karena meliputi sikap menyukai organisasi dan kesediaan untuk mengusahakan tingkat upaya yang tinggi bagi kepentingan organisasi demi pencapaian tujuan. MenurutZurnali (2010), komitmen merupakan perasaan yang kuat dan erat dari seseorang terhadap tujuan dannilai suatu organisasidalam hubungannyadenganperan mereka terhadap upaya pencapaian tujuan dan nilai-nilai tersebut.

Berdasarkan pendapat para ahli di atas dapat ditarik kesimpulan bahwa komitmen karyawan adalah tingkatan dimanaseorangkaryawan mengidentifikasikan diri dengan perusahaan dan tujuan-tujuannya dan merupakan salah satu sikap yang merefleksikan perasaan suka atau tidak suka dari seorang karyawan terhadap perusahaan tempat dia bekerja serta berkeinginan untuk memelihara keanggotaannya dalam perusahaan, karena komitmen karyawan merupakan dimensi perilaku penting yang dapat digunakan untuk menilai kecenderungan pegawai, identifikasi dan keterlibatan seseorang yang relatif kuat terhadap perusahaan serta bersedia berusaha keras bagi pencapaian tujuan organisasi.

Menurut Minner dalam Sopiah (2008) mengemukakan empat (4) faktor yang mempengaruhi komitmen karyawan antara lain :

Faktor persona, misalnya usia, jenis

kelamin, tingkat pendidikan, pengalaman kerja, dan kepribadian.

Karakteristik pekerjaan, misalnya lingkup jabatan, tantangan dalam pekerjaan, konflik peran, tingkat kesulitan dalam pekerjaan.

Karakteristik struktur, misalnya besar kecilnya organisasi, bentuk 
organisasi, kehadiran serikat pekerjan, dan tingkat pengendalian yang dilakukan organisasi terhadap karyawan.

Pengalaman kerja. Pengalaman kerja seorang karyawan sangat

berpengaruhterhadaptingkat

komitmen karyawan pada organisasi. Karyawan yang baru beberapa tahun bekerja dan karyawan yang sudah puluhan tahun bekerja dalam organisasi tentu memiliki tingkat komitmen yang berlainan.

Jadi, faktor-faktor yang mempengaruhi komitmen karyawan ada empat faktor diantaranya faktor personal, karakteristik jabatan, karakteristik struktur dan pengalaman kerja, sehingga dengan adanya faktor-faktor tersebut maka karyawan memiliki komitmen terhadap pekerjaan dan perusahaan dimana mereka bekerja.

Pengembangan Karir Menurut Casiodalam kutipan Wahyudi (2007) mengatakan bahwa karir adalah "Rangkaian promosi jabatan atau mutasi jabatan yang lebih tinggi dalam jenjang hirarki yang dialami oleh seorang karyawan selama masa kerjanya". Menurut Rivai (2008) mengemukakan bahwa "Pengembangan karir adalah proses peningkatan kemampuan kerja individu yang dicapai dalam rangka mencapai karir yang diinginkan".

Menurut Mejia (2007) pengembangan karir dapat diartikan sebagai upaya formal dan berkelanjutan yang berfokus pada pengembangan terhadap karyawan yang lebih baik. Menurut Dessler dan Tan Chwee Huat (2009) pengembangan karir merupakan rangkaian kegiatan seumur hidup.

MenurutMondy (2010) pengembangan karir adalah pendekatan formal yang digunakan perusahaan untuk memastikan bahwa orang-orang dengan kualifikasi dan pengalaman yang tepat, tersedia saat dibutuhkan. Pengembangan karir merupakan kesempatan bagi karyawan naik jabatan dalam organisasi.

Dengan demikian, pengembangan karir merupakan proses pengembangan minat dan bakat untuk karyawan dalam kesempatan menaiki jenjang jabatan yang lebih tinggi lagi dalam suatu perusahaan. Tujuan dari pengembangan karir adalah untuk menyesuaikan antara kebutuhan dan tujuan karyawan dengan kesempatan karir yang tersedia di perusahaan untuk masa sekarang dan masa depan. Seperti yang dikemukakan oleh Rivai (2008) bahwa pengembangan karir yang dirancang dengan baik akan membantu karyawan dalam menentukan kebutuhan karir mereka sendiri, dan

Menyesuaikanantara kebutuhan karyawan dengan tujuan perusahaan. Menurut Mangkunegara (2009) adapuntujuan pengembangan

karir adalah sebagai berikut :

Membantu dalam pencapaian tujuan individu dan perusahaan 
Menunjukkan kebutuhan kesejahteraan pegawai

Membantu pegawai menyadari kemampuan potensi mereka

Memperkuat hubungan antara pegawai dan perusahaan

Membuktikantanggung jawab sosial

Membantu memperkuat pelaksanaan program-program perusahaan agar tujuan perusahaan tercapai

Mengurangi turnover dan biaya kepegawaian

Mengurangi keusangan profesi dan manajerial

Menggiatkan analisis dari keseluruhan pegawai

Mengintegrasikan perencenaan

kerja dan kepegawaian.

\section{KinerjaKaryawan}

Kinerja dalam sebuah organisasi merupakan salah satu unsur yang tidak dapat dipisahkan dalam menjalankan tugas organisasi, baik itu dalam lembaga pemerintahan maupun swasta. Kinerja berasal dari bahasa job performance atau actual performance (prestasi kerja atauprestasi sesungguhnya yang dicapai oleh seseorang atau suatu institusi). Kinerja pegawai pada dasarnya terbentuk setelah pegawai merasa adanya kepuasan, karena kebutuhannya terpenuhi dengan kata lain apabila kebutuhan pegawai belum terpenuhi sebagaimana mestinya maka kepuasan kerja tidak akan tercapai, dan pada hakikatnya kinerja pegawai akan sulit terbentuk.

Sebagaimana dikemukakan oleh Mangkunegara (2009) bahwa istilah kinerja berasal dari kata job performance atau actual performance (prestasi kerja atauprestasi sesungguhnya yang dicapai seseorang) yaitu hasil kerja secara kualitas dan kuantitas yang dicapai oleh seorang pegawai dalam melaksanakan tugasnya sesuai dengan tanggung jawab yang diberikan kepadanya. Menurut Rivai (2008) bahwa kinerja merupakan perilaku nyata yang ditampilkan setiap orang sebagai prestasi kerja yang dihasilkan oleh karyawan sesuai dengan perannya dalam perusahaan. Kinerja adalah suatu hasil kerja yang dicapai oleh seseorang dalam melaksanakan tugas-tugas yang dibebankan kepadanya yang didasarkan atas kecakapan, pengalaman dan kesungguhan waktu yang diukur dengan mempertimbangkan kuantitas, kualitas dan ketepatan waktu.

Kinerja merupakan perwujudan kerja yang dilakukan oleh karyawan atau organisasi yang bersangkutan. Kinerja dapat

diukur melalui pengukuran tertentu (standar) dimana kualitas adalah berkaitan dengan mutu kerja yang dihasilkan, sedangkan kuantitas adalah jumlah hasil kerja yang dihasilkan dalam kurun waktu tertentu, dan ketepatan waktu adalah kesesuaian waktu yang telah direncanakan. Kinerja merupakan suatu fungsi dari

motivasi dan kemampuan, untuk menyelesaikan tugas atau pekerjaan seseorang harus memiliki derajat kesediaan dan tingkat kesediaan tertentu, kesediaan dan keterampilan seseorang 
sangatlah tidak cukup efektif untuk mengerjakan sesuatu tanpa pemahaman yang jelas tentang apa yang akan dikerjakan dan bagaimana mengerjakannya.

Setiap orang yang bekerja digerakan oleh suatu motif. Motif pada dasarnya bersumber pertamatama berbagai kebutuhan dasar individu atau dapat dikatakan bahwa kekuatan yang memotivasi seorang untuk bekerja giat dalam pekerjaanya tergantung dari hubungan timbal balik antar apa yang diinginkan atau dibutuhkan dari hasil pekerjaan tersebut dan seberapa besar keyakinan organisasi akan memberikan kepuasan bagi keinginannya sebagai imbalan atas usaha yang dilakukannya.

Konsep kinerja pada dasarnya merupakan perubahan atau pergeseran paradigma dari konsep produktivitas. Orang sering menggunakan istilah produktivitas untuk menyatakan kemampuan seseorang atau organisasi dalam mencapai tujuan atas sasaran tertentu, paradigma produktivitas yang baru adalah paradigma kinerja secara aktual yang menuntut pengukuran secara aktual keseluruhan kinerja organisasi, tidak hanya efesiensi atau dimensi fisik, tetapi juga dimensi non fisik.

Berdasarkan pengertianpengertian kinerja dari beberapa pendapat diatas, dapat disimpulkan bahwa kinerja merupakan hasil kerja baik itu secara kualitas maupun kuantitas yang telah dicapai pegawai, dalam menjalankan tugas-tugasnya sesuai dengan tanggung jawab yang diberikan organisasi, dan hasil kerjanya tersebut disesuaikan dengan hasil kerja yang diharapkan organisasi, melalui kriteria-kriteria atau standar kinerja pegawai yang berlaku dalam organisasi.

\section{Kerangka Konseptual}

Untuk menciptakan kinerja yang tinggi dibutuhkan adanya peningkatan kerja yang optimal dan mampu memberdayakan potensi yang dimiliki oleh karyawan guna menciptakan tujuan organisasi sehingga akan memberikan kontribusi yang positif bagi perkembangan organisasi. Selain itu, pemimpin perlu memperhatikan berbagai faktor yang dapat mempengaruhi kompetensi, komitmen dan pengembangan karir, dalam hal ini diperlukan adanya peran organisasi dalam meningkatkan kinerja karyawan yang mendorong terciptanya sikap dan tindakan yang professional dalam menyelesaikan pekerjaan sesuai dengan bidang dan tanggungjawab masingmasing karyawan.

Penelitian olehShaputradan Hendriani (2015) dengan adanya kompetensi, komitmen dan pengembangan karir yang dirasakan karyawan, maka karyawan akan akan melaksanakan seluruh tanggungjawab guna mencapai kinerja yang tinggi. Penjelasan keterkaitan antara kompetensi, komitmen dan pengembangan karir terhadap kinerja karywan dapat digambarkan dalam kerangka konseptual sebagai berikut :

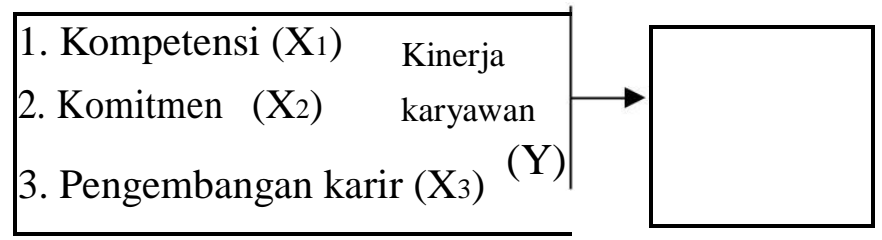


Sumber : Shaputra dan Hendriani (2015), Data

Diolah (2016).

G

Gambar 1 Kerangka Konseptual

\section{Hipotesis Penelitian}

Adapun hipotesis pada penelitian

ini adalah :

1. Kompetensi secara parsial

berpengaruh terhadap kinerja

karyawan.

2. Komitmen secara parsial

berpengaruh terhadap kinerja

karyawan.

Pengembangan karir secara parsial berpengaruh terhadap kinerja karyawan

Kompetensi, komitmen dan pengembangan karir berpengaruh secara serempak terhadap kinerja karyawan.

\section{METODE PENELITIAN}

Populasi dan Sampel Penelitian Populasi adalah sekelompok

orang, kejadian atau segala sesuatuyang mempunyai karakteristik tertentu, sedangkan sampel adalah bagian dari populasi yang diambil melaui cara-cara tertentu yang juga memiliki karakteristik tertentu, jelas dan lengkap yang dianggap bisa mewakili populasi. Dalam menetapkan besarnya sampel (sampel size) dalam penelitian ini menggunakan sampel non probability yaitu sampel jenuh,dimana semua populasi dijadikan sampel. Biasanya hal ini terjadi karena jumlah populasi atau sampel berjumlah 45 responden yang merupakan seluruh karyawan PT.Prudential Life Assurance Rantauprapat.

\section{Sumber Data}

Selain jenis data, dalam penelitian ini juga digunakan beberapa sumber data yaitu :

Data Primer Data yang diperoleh melalui pengamatan dan wawancara langsung dengan pimpinan dan staf serta karyawan perusahaan yang berkompeten dan ada kaitannya dengan obyek penelitian ini.

Data Sekunder Data yang diperoleh 
berupa dokumen perusahaan, literature serta artikel yang relevan dengan objek penelitian. Misalnya bukubuku referensi, jurnal-jurnal umum dan internasional, literature tambahan yang validitasnya dapat

dipertanggungjawabkan oleh penulis.

\section{Teknik Pengumpulan Data}

Guna memperoleh data dan informasi menyangkut materi penulisan ini, maka penulis menggunakan metode pengumpulan data sebagai berikut :

Observasi yaitu penelitian yang dilakukan dengan mengunjungi secara langsung objek penelitian untuk mendapatkan data-data yang diperlukan dalam penelitian ini.

Dokumentasi yaitu penelitian yang dilakukan dengan mengumpulkan dokumendokumen atau arsip yang ada kaitannya dengan masalah yang terjadi.

\section{Metode Analisis Data}

Metode analisisdata pada penelitian ini yaitu :

1.Deskriptif Statistik Analisis deskriptif,merupakan suatu cara menganalisisdimana data yang sudah dikumpulkan, dikelompokkan, dianalisis dan diinterpretasikan sehingga diperoleh gambaran yang jelas tentang objek yang diteliti.

2. Analisis Regresi Linier Berganda Dalam mengetahui hubungan dan pengaruh antara kompetensi, komitmen dan pengembangan karir terhadap kinerja karyawan digunakan metode analisis regresi berganda, untuk mengetahui besarnya pengaruh secara kuantitatif dari suatu perubahan (variabel independen) terhadap kejadian lainnya (variabel dependen). Analisis regresi berganda menggunakan persamaan,

sebagai berikut:

$=\mathrm{a}+\mathrm{b}_{1} \mathrm{X}_{1}+\mathrm{b}_{2} \mathrm{X}_{2}+\mathrm{b}_{3} \mathrm{X}_{3}+\mathrm{e}$ Keterangan :

$=$ Kinerja karyawan $\mathrm{a}=$ Nilai intercept

$\mathrm{b}_{1}-\mathrm{b}_{3}=$ Koefisien Regresi yang

akan dihitung

$\mathrm{X}_{1} \quad=$ Kompetensi

$\mathrm{X}_{2}=$ Komitmen

$\mathrm{X}_{3}=$ Pengembangan karir e $=$

\section{Standart error PEMBAHASAN}

Pembahasan

Secara Serempak Kompetensi, Komitmen dan Pengembangan Karir Berpengaruh Positif dan 


\section{SignifikanTerhadap Kinerja Karyawan.}

Secara serempak variabel kompetensi, komitmen dan pengembangan karir berpengaruh positif dan signifikan terhadap kinerja karyawan. Sebagai jalan untuk lebih meningkatkan kinerja karyawan, berkaitan dengan kompetensi karyawan dan hubungannya dengan peningkatan kinerja karyawan, PT Prudential Life Assurance Rantauprapat mengembangkan model kompetensi yang berintegrasi dengan tolak ukur penilaian kinerja berdasarkan pengetahuan, keterampilan, perilaku yang dimiliki oleh setiap karyawan agar dapat mempermudah di dalam melaksanakan tugas dan tanggung jawab secara efektif. Upaya untuk meningkatkan kompetensi karyawan dilakukan melalui program pelatihan yang sesuai dengan bidang tugas masing-masing. Selanjutnya dalam dunia kerja, komitmen karyawan terhadap perusahaan seringkali menjadi isu yang sangat penting agar tercipta kondisi dan iklim kerja yang kondusif sehingga perusahaan dapat berjalan secara efisien dan efektif. Iklim kerja PT Prudential Life

Assurance Rantauprapat menunjang, misalnya fasilitas memadai, hubungan kerja

yang harmonis, jaminan sosial dan keamanan jelas, maka secara otomatis komitmen individu terhadap organisasi menjadi semakin kuat atau bahkan cenderung semangat ditempat kerjanya. Sementara itu dari aspek pengembangan karir karyawan, PT Prudential Life Assurance Rantauprapat memberi perhatian khusus terhadap pengelolaan sumberdaya manusia. PT Prudential Life

Assurance Rantauprapat telah memberikan berbagai saran dan rekomendasi dengan tetap memperhatikan peningkatan kualitas sumberdaya anusia melalui penyempurnaan kualitas pendidikan dan pelatihan. Dalam pelaksanaan trategi pengembangan karir, pimpinan menekankan pengalaman yang

disertai kompetensi dan kualitas kepemimpinan, serta memberi perhatian khusus terhadap pengembangan kompetensi dan pengalaman para pekerja baru yang merupakan calon-calon profesional di masa depan. Sebagaimana penelitian Shaputra dan Hendriani (2015) mengatakan variabel kompetensi, komitmen dan pengembangan karir berpengaruh pada kinerja karyawan.

\section{2) Secara ParsialKompetensi}

\section{Berpengaruh Positif dan}

\section{Signifikan Terhadap Kinerja Karyawan.}

Secara parsial parsial kompetensi berpengaruh positif dan signifikan terhadap kinerja karyawan. Kompetensi adalah keterampilan yang diperlukan seseorang yang ditunjukkan oleh kemampuannya untuk dengan konsisten memberikan tingkat kinerja yang memadai atau tinggi dalam suatu fungsi pekerjaan spesifik. Kompetensi harus dibedakan dengan kompetensi, walaupun dalam pemakaian umum istilah ini digunakan dapat dipertukarkan. Upaya awal untuk menentukan kualitas dari manajer yang efektif didasarkan pada sejumlah sifat-sifat kepribadian dan 
keterampilan manajer yang ideal. Ini adalah suatu pendekatan model input, yang fokus pada keterampilan yang dibutuhkan untuk mengerjakan suatu pekerjaan. Keterampilanketerampilanini adalah kompetensi dan mencerminkan kemampuan potensial untuk melakukan sesuatu. Dengan munculnya manajemen ilmiah, perhatian orang-orang berbalik lebih pada perilaku para manajer efektif dan pada hasil manajemen yang sukses. Pendekatan ini adalah suatu model output, dengan mana efektivitas manajer ditentukan, yang menunjukkan bahwa seseorang telah mempelajari bagaimana melakukan sesuatu dengan baik. Kompetensi juga digunakan dalam manajemen imbalan, sebagai contoh, dalam pembayaran berdasarkan kompetensi. Penilaian kompetensi adalah suatu proses yang perlu untuk menyokong inisiatifinisiatif ini dengan menentukan kompetensi-komptensi apa yang karyawan harus perlihatkan. Pendapat yang hampir sama dengan konsep Inggris dikemukakan olehKravetz (2004), bahwa kompetensi adalah sesuatu yang seseorang tunjukkan dalam kerja setiap hari. Fokusnya adalah pada perilaku di tempat kerja, bukan sifat-sifat kepribadian atau keterampilan dasar yang ada di luar tempat kerja ataupun di dalam tempat kerja. Kompetensi mencakupmelakukan sesuatu, tidak hanya pengetahuan yang pasif. Seorang karyawan mungkin pandai, tetapi jika mereka tidak menterjemahkan kepandaiannya ke dalam perilaku di tempat kerja yang efektif, kepandaian tidak berguna. Jadi kompetensi

tidak hanya mengetahui apa yang harus dilakukan. Sebagaimana penelitian Shaputra dan Hendriani (2015) mengatakan variabel kompetensi, komitmen dan pengembangan karir berpengaruh pada kinerja karyawan.

\section{Secara Parsial Komitmen Tidak Berpengaruh Positif dan Tidak Signifikan Terhadap Kinerja Karyawan.}

Secara parsial komitmen tidak berpengaruh positif dan tidak signifikan terhadap kinerja karyawan. Komitmen merupakan sikap dan perilaku untuk mendorong diri sendiri memenuhi dan melampaui sesuatu yang menjadi kewajiban dan tugasnya. Seseorang dengan komitmen tinggi akan selalu mampu menyelesaikan tanggung jawabnya, walaupun ada banyak kesulitan dan kendala yang dihadapi. Di dalam komitmen ada keinginan untuk bertanggung jawab, ada keuletan, ketahanan, kedisipinan, keikhlasan, dan keinginan berbuat lebih melalui aktualisasi diri. Untuk mendorong sikap dan perilaku tersebut bukan pekerjaan mudah. Seseorang harus memiliki motivasi yang kuat untuk dapat memiliki sikap tersebut. Namun demikian, organisasi harus mendorong untuk peningkatan komitmen tersebut. Walaupun komitmen lebih potensial digerakkan oleh faktor internal dalam diri seseorang namun organisasi harus melakukan upaya untuk menumbuhkan komitmen dalam diri seseorang. Upaya tersebut dapat dilakukan melalui; 1) keteladanan. Keteladanan dilakukan oleh pemimpin untuk mendorong tumbuhnya nilai-nilai yang kemudian akan mendorong tumbuhnya motivasi dan semangat kerja. Tumbuhnya motivasi dan semangat kerja ini akan mendorong tumbunnya komitmen, 2) mengembangkan budaya organisasi yang mengarah kepada terbentuknya komitmen bagi seluruh komponen yang ada di dalam organisasi. Ditumbuhkannya nilainilai ikhlas, ulet, pantang menyerah, suka menolong, dan bekerja keras merupakan hal penting untuk tumbuhnya nilai ini. Proses penumbuhannya dilakukan melalui keteladanan, dan pengembangan sistem kerja yang mendukung terciptanya nilai-nilai ini. 3) pelatihan tentang penumbuhan motivasi dan komitmen dapat juga menjadi satu upaya penyadaran dalam proses penumbuhan komitmen, Proses penumbuhan seringkali 
dilakukan melalui kegiatan-kegiatan penyadaran dan simulasi terhadap kondisi-kondisi tertentu, keseluruhan kegiatan diarahkan untuk menumbuhkan kesadaran tentang pentingnya komitmen. Sebagaimana penelitian Shaputra dan Hendriani (2015) mengatakan variabel kompetensi, komitmen dan pengembangan karir berpengaruh pada kinerja karyawan.

\section{Secara Parsial Pengembangan Karir Berpengaruh Positif dan Signifikan Terhadap Kinerja Karyawan.}

Secara parsial pengembangan karir berpengaruh positif dan signifikan terhadap kinerja karyawan. Pengembangan karir pada dasarnya berorientasi pada perkembangan perusahaan/ organisasi dalam menjawab tantangan bisnis di masa mendatang. Setiap organisasi harus menerima kenyataan, bahwa ekstensinya di masa depan tergantung pada sumber daya manusia yang kompetitif sebuah organisasi akan mengalami kemunduran dan akhirnya dapat tersisih karena ketidak mampuan menghadapi pesaing. Dengan kata lain, pembinaan karier adalah salah satu kegiatan menejemen sumber daya manusia, harus dilaksanakan sebagai kegiatan formal yang dilakukan secara terintegrasi dengan kegiatan sumber daya manusia lainnya. Dari uraian diatasberarti pembinaan karier tidak dapat dilepaskan kaitannya dengan kegiatan perencanaan sumber daya manusia, rekrutmen, dan seleksi dalam rangka

pengaturan staf (staffing). Dari kegiatankegiatan manajemen sumber daya manusia tersebut, harus diperoleh sejumlah tenaga kerja yang potensial dengan kualitas terbaik. Tenaga kerja seperti itulah yang

harus diberi kesempatan untuk mengembangkan kariernya, agar dengan kemampuannya yang terus meningkatkan sesuai dengan tuntutan lingkungan bisnis, tidak saja mampu mempertahankan eksistensi organisasi, tetapi juga mampu

mengembangkan dan memajukan. Sebagaimana penelitian Shaputra dan Hendriani (2015) mengatakan variabel kompetensi, komitmen dan pengembangan karir berpengaruh pada kinerja karyawan

\section{KESIMPULAN}

Adapun kesimpulan pada penelitian ini sebagai berikut :

1. Secara serempak variabel kompetensi, komitmen dan pengembangan karir berpengaruh positif dan signifikan terhadap kinerja karyawan.

Secara parsial parsial kompetensi berpengaruh positif dan signifikan terhadap kinerja karyawan.

Secara parsial komitmen tidak berpengaruh positif dan tidak signifikan terhadap kinerja karyawan. 
Secara parsial pengembangan karir berpengaruh positif dan signifikan terhadap kinerja karyawan.

\section{DAFTAR PUSTAKA}

Arjulis, A., Wibowo, E. A., \&Oktavianti, O. (2017). Pengaruh Kompensasi Terhadap KinerjaKaryawanPT. Djarum Tbk Cabang Batam DenganMotivasi Kerja Sebagai VariabelIntervening. Equilibiria, 4(2).

Bambang, Wahyudi. 2007. Manajemen Sumber Daya Manusia.

Bandung : Sulita.

Dessler G, dan Tan Chwee Huat. 2009. Human Resource Management : An Asian. Perspective. Singapore :Prentice Hall Pearson Education South Asia PTE.

Ghozali, Imam. 2013. Aplikasi Analisis Multivariat dengan

Program IBM SPSS. 21. Edisi 7,Penerbit Universitas Diponegoro.

Kaseger G Regina. 2013. Pengembangan Karir dan Self Efficacy Terhadap Kinerja Karyawan Pada PT.

MatahariDepartment Store Manado Town Square. Jurnal Emba.

Universitas Sam Ratulangi Manado. ISSN 23031174, Vol 1 No. 4 Desember 2013, Diakses 08 juni 2014. Hal. 906-916.

Kuntjoro, Zainuddin $\quad$ Sri. 2006.2 Komitmen Organisasi.

Jakarta.http://www.epsikologi.com/masalah 